\title{
O teatro no Brasil e a representação do Holocausto: Samuel Rawet e Hilda Hilst
}

\author{
Berta Waldman \\ USP - CNPq
}

\section{I - "O lance de dados"}

Se Deus não existe, tudo é permitido.

Fiódor Dostoievsky (Irmãos Karamazov)

Samuel Rawet ${ }^{1}$ (1929, Klimontow-Polônia - 1984, Sobradinho-Brasília), escritor que viveu no Brasil a maior parte de sua vida, além de contista e ensaísta teve uma participação pouco divulgada na história da dramaturgia nacional. Integrou o grupo Café da manhã criado por Dinah Silveira de Queiróz, do qual participaram também Fausto Cunha, Renard Perez, Fábio Lucas, Nataniel Dantas e outros interessados em teatro. Escreveu peças como “Os Amantes”, de 1957, que chegou a ser encenada no Teatro Municipal do Rio de Janeiro. Já "O lance de dados", trabalho inédito ${ }^{2}$ sobre um colaborador judeu durante a Segunda Guerra Mundial, não foi representado. Sabe-se que Rawet pretendia publicá-lo pela editora Vertente, por volta de 1977, mas isso não ocorreu. Apesar de a ficção de Rawet ter sido reunida e publicada, o teatro mantém-se em parte inédito.

O título da peça alude diretamente ao título do poema de Stéphane Mallarmé (1842-1898) “Um lance de dados” (em francês, "Un coup de dés"), publicado em fins do século XIX. Esse poema permite várias possibilidades de leitura devido à disposição não linear dos versos, que inclusive traçam um desenho labiríntico, que parte do verso inicial, "Un coup de dés jamais n'abolira le hasard", recuperado no final do poema.
1. A obra ficcional de Samuel Rawet mereceu organização e republicação recente. Ver Contos e Novelas Reunidos (org. André Seffrin), 2004.

2. Agradeço ao pesquisador e crítico literário André Seffrin os originais da peça gentilmente cedidos. [Os números de páginas correspondem a esses originais]. 
A indeterminação e a imprevisibilidade sugeridas aludem à impossibilidade de enfeixar uma constelação de possíveis num projeto único. $\mathrm{O}$ acaso do jogo de dados está em que o resultado de um determinado lance independe de toda a sequência histórica dos lances anteriores, ou seja, o lance não tem passado, e a direção dos resultados pode mudar completamente a qualquer momento.

$\mathrm{Na}$ dobra metalinguística, o poema aponta para o processo de criação, situando-o no intervalo entre a contingência e a necessidade; a primeira conduz o processo à diversidade; a segunda, à eficiência.

Alterando o artigo indefinido que passa a definido, o título da peça de Rawet - "O lance de dados" - afunila a ideia de jogo a uma referência única, restringindo-lhe a multiplicidade de alternativas. Além disso, "O lance de dados" também pode ser lido como "dados (informações antes ocultas) que vão sendo lançados, apresentados”. A análise do título será retomada ao longo do estudo da peça.

"O lance de dados" compõe um teatro de significações, intensidades, forças e pulsões de presença. $\mathrm{O}$ caráter estático dessa dramaturgia, com tendência ao diálogo repetitivo, opõese à dinâmica progressiva e linear do drama. Nela, mais que ação, importa a situação.

Ainda que a peça de Rawet não apresente uma ação no sentido do claro desenvolvimento de uma fábula, ela ativa sua dinâmica por meio da mudança de situações, espécie de quadros em movimento e instalações provisórias que viabilizam o encadeamento do espetáculo, com base em acirradas competições de palavras e silêncios, numa sucessão de quadros com pouca tensão e algum suspense.

A exigência de uma experiência mais partilhada que transmitida, mais impulso de energia que informação, constrói-se a partir de uma "palheta estilística" composta pela parataxe, determinante de estruturas não-hierarquizadas, em que os elementos cênicos não se ligam uns aos outros de forma evidente, além de não se ilustrarem, nem funcionarem por mecanismos de reforço e redundância.

Para resistir ao bombardeio de informações, a peça adota uma estratégia de economia dos elementos cênicos, em processos de repetição e ênfase na duração ou no ascetismo dos espaços vazios. Privilegiando o silêncio, o vazio e a redução minimalista dos gestos e dos movimentos, criam-se elipses a serem preenchidas pelo espectador, de quem se exige uma postura produtiva.

Certamente, a peça insere-se nas transformações ocorridas no teatro pós Segunda Guerra Mundial, quando as elites testemunharam, com inegável espanto, a emergência de novos 
dramaturgos, que produziram retratos bem pouco lisonjeiros do período. Neste "novo teatro" despontam Beckett, Ionesco, Adamov, Sartre, Camus, Genet, Osborne, Albee, Gelber, Dürrenmatt, entre outros, todos eles relacionados a uma nova estética, qualificada genericamente por Geneviève Serreau como um "teatro de irrisão". ${ }^{3}$

Também no Brasil, entre 1960 e 1970, diversos espetáculos exacerbaram as características modernistas, incidindo num ultramodernismo experimental que serviu como antessala para a pós-modernidade. O primeiro deles é $O$ rei da Vela, texto de 1933 de Oswald de Andrade, encenado pelo Teatro Oficina em 1967, sob a direção de José Celso Martinez Corrêa. Considerado não-montável durante décadas, o texto reuniu na ocasião plenas condições de existência no palco, no centro do redemoinho advindo com o estro de Artaud, Brecht e Grotóvski, submersos em generoso banho tropicalista. Cemitério de Automóveis, no mesmo ano, escancarou com agudeza nunca vista o universo sadomasoquista de Arrabal, pelas mãos do argentino Victor García que, dois anos mais tarde, apresenta de forma exuberante $O$ Balcão, de Jean Genet, organizando metáforas e alegorias vetorizadas em retórica neobarroca, num inusual espaço vertical. ${ }^{4}$

\section{2.}

"O Lance de dados" conta com cinco personagens: Jonas, Helena, Ana, Marcos e Júlia. O cenário é único, o salão de estar de uma residência em Santa Teresa, mantendo-se de começo a fim. O palco funciona como uma espécie de espaço alegórico da História, que não existe nas imagens externas, mas nas subjetividades em confronto. O protagonista é Jonas, herói que não se sustenta numa individualidade psicológica, sendo antes a expressão de um movimento interior de ideias e ideais que encontra eco na utilização simbólica de elementos cênicos. Como já mencionado, a ação é desdramatizada: não há um encaminhamento lógico com começo, meio e fim, e sim uma sucessão de episódios justapostos. O período abarcado pela peça é o de alguns anos após o fim da Segunda Guerra Mundial.

Jonas está sentado, lê um livro e, ao seu lado, há uma taça de chá. Helena entra trazendo o barulho de fora - é Carnaval. Ela conta que viu um bloco e comenta a alegria mesclada com melancolia ${ }^{5}$, na canção, na dança requintada. Helena tenta imitá-la, faz as vezes da negra gorda, ótima bailarina. A condição estrangeira dos dois é logo denunciada, no tipo
3. Geneviève Serreau (Histoire du "Nouveau Théâtre"; 1964), apud. GINSBURG, Jacó; BARBOSA, Ana Mae (orgs.). O Pós-Modernismo, São Paulo: Perspectiva, 2005, p. 561.

4. Cf. MOSTAÇO, Edélcio. O teatro Pós-moderno, 2005, p.571.

5. Paulo Prado, em Retrato do Brasil: ensaio sobre a tristeza brasileira (1929, p. 514), afirma em relação à cultura popular de que eram expressão o bumbameu-boi, o cavalo-marinho, a festa de Reis, nas quais a risada do negro quebrava "a apagada e vil tristeza", que aos poucos tomara conta das casas-grandes. Prado considerava que não só negros e mulatos eram tristes, como também o caboclo, calado, desconfiado, era "quase um doente em sua tristeza" (p. 512). 
de olhar que lançam à festa, na qual percebem uma notação de tristeza, estabelecendo-se uma distância entre o casal e os da terra. Quem são os requintados? Essa questão é levantada e Jonas manifesta-se:

"E os requintados somos nós... (Amargo) animais enfarpelados com uma carapaça de cultura...” (p. 3)

Há um travo amargo na conversa dos dois, enquanto tomam chá, hábito europeu mantido. Vê-se que não é amor ou paixão que une o casal, mas uma necessidade que se formaliza numa decisão racional de manter os monstros adormecidos.

O casal encontrou-se pela primeira vez em janeiro de 1948, na mesa de um bar, em Berlim. Ela estava assustada e odiava os que agiam como se nada tivesse acontecido. $\mathrm{O}$ que aconteceu é elíptico na peça, mas a referência são os campos de extermínio nazistas. As falas são filosóficas, extensas, e não há preocupação em dar-lhes o tom de naturalidade. Reatar uma vida ordenada, sem esperanças de qualquer espécie, nem projetos otimistas, esse é o impulso de Jonas.

"Garantimos a solidão necessária de cada um, e a comunicação suficiente para afastar-nos do desespero. Em outras condições, poderia dizer que sou feliz.” (p. 8)

$\mathrm{Na}$ peça, a tonalidade filosófica é sempre guiada pelo personagem masculino.

Os dois se encontraram numa madrugada e resolveram se vincular em nome do passado comum (os dois são judeus, tinham os mesmos hábitos, a mesma cultura, e foram submetidos aos mesmos princípios de exclusão).

Nessa altura, há uma volta ao presente da ação e é sextafeira. Helena busca castiçais, velas, fósforos para acender as velas de shabat.

Helena era de uma aldeia e sua família só pensava em arranjar-lhe um noivo.

A exterioridade das marcas judaicas faz emergir a pergunta: o que é ser judeu? Pergunta que será retomada em diferentes momentos da peça.

Entra em cena uma terceira personagem - Ana, anunciada anteriormente.

Helena chora em seu colo. As duas tinham estado no mesmo campo de concentração (não nomeado) e mencionam o medo vivido no campo, medo de ser escolhida para morrer. A questão dos mortos e dos sobreviventes é posta na peça e também a necessidade da memória e do testemunho.

Jonas é apresentado a Ana, que o fita insistentemente, mas cala tê-lo reconhecido. 
Ana comunica que Marcos vive com ela, que Kátya (filha?) morreu alguns meses antes do fim da guerra, e sai de forma abrupta e perturbada.

O primeiro ato apresenta duas personagens sobreviventes da Guerra, unidas por um casamento baseado em acordos; já o segundo ato remete à quebra da harmonia desta união, através do aparecimento de uma terceira personagem, também sobrevivente do Holocausto. Introduz-se um clima de suspense com uma chamada telefônica.

Jonas prossegue em tom filosófico tratando da ideia de Deus, lançada primeiramente por Helena:

Helena: "Como era boa e calma a entrega de nós mesmos a um ente supremo.” (p. 16)

Jonas: Sem Deus, somos todos homens limitados pelo nascimento e pela morte. Qualquer idéia que procure nos fixar um sentido para além dos limites de nossa existência é apenas um substituto do que se eliminou. O que sobra somos nós mesmos, divididos, empenhados numa ação, atordoados, mas limitados pela morte inevitável. E é com o horror dessa visão que aguardamos o nosso muro. $\mathrm{Ne}$ nhuma esperança para nossas faltas, faltas impostas por uma consciência criada por séculos de crença, e que, agora, despida desse halo, vêm com os imperativos da lei. (p. 16)

Helena recusa-se a acompanhar as elucubrações do marido transtornado, atenta para o céu azul, limpo de nuvens. Eles não olham mais para a mesma direção. Com os elementos trazidos com a entrada de Ana, a união do casal se quebra.

Enquanto Helena quer uma mudança na atmosfera conjugal, talvez um filho, Jonas quer a repetição do mesmo, e o casal começa a falar em separação.

A entrada de Ana na vida do casal torna incômoda a bolha em que vivem. O desespero de Ana faz Helena ver que o mundo prossegue. Ela se dá conta de que vive na aceitação do que lhe vem às mãos; acredita que só um filho poderia tirá-los do universo de frases, da atmosfera saturada de decisões lógicas.

Jonas reluta: "O que temos para lhe oferecer, a não ser o produto de duas neuroses?” (p. 22)

Passos de Jonas em direção à porta de entrada. Deixa-a aberta. Acende a luz. Entra a empregada, vinda do interior.

Júlia - a empregada - conta que Helena saiu nervosa, depois de um telefonema, dizendo que iria à casa de dona Ana e não sabia a que horas voltaria. É sábado de carnaval, e a empregada quer sair. Ela vai, depois de servir um chá.

Surge Marcos, armado, nervosíssimo.

Jonas se dá conta, pelo sotaque, que o outro era estrangei- 
ro, judeu como ele, e devia estar no país há menos de um ano. Marcos aponta-lhe um revólver para pôr fim "à vida sórdida, essa vida que para se salvar... de que não foi capaz?” (p. 25)

A alusão a algo ocorrido no passado retorna e o leitor percebe que a presença de Marcos significa um acerto de contas. O comportamento deste é impulsivo, raivoso, empolgado, contrastando com a atitude controlada de Jonas. Marcos é um homem de ação, uma figura heroica, que pode matar por uma ideia. Jonas vai até uma cômoda e dela retira um arsenal de suicida: um punhal, uma corda com laço feito, frascos de tóxico, seringas, ampolas, uma navalha, um revólver, aguardando a decisão anunciada por Marcos. Enquanto grita que Jonas é um monstro, este replica, chamando-o "herói de merda!” Marcos revela ser filho de Ana e afirma que está disposto a "matar um homem que durante a guerra, enquanto os judeus morriam, colaborou com os alemães, fez fortuna, e apesar disso, continua vivo. (Pausa) Eis a minha biografia, sumária, mas só essa lhe interessa /.../” (p. 26)

Jonas oferece dinheiro a Marcos, que recusa. Jonas apunhala Marcos no peito.

A empregada apreensiva chama por Jonas, que lhe diz:

"Não foi nada, Júlia! Nada! (Pausa) Apenas um ladrão! Apenas um ladrão” (p. 27)

Jonas está deitado no sofá, ao entardecer. Helena aparece e atravessa a sala. Ele narra a Helena um conto hassídico de um discípulo de Baal Shem Tov que era coxo e relata o entusiasmo de seu mestre quando se punha a rezar e como bailava e saltitava embriagado pela oração. $O$ entusiasmo do discípulo era tal que, ao imitar o mestre, passa a saltar e a dançar, curando-se de seu mal. Jonas gostaria de contar uma história, mas falta-lhe o mestre.

Outro relato de Jonas concentra-se em sua cidade natal, onde também vivia um homem baixo, gordo, pernas arqueadas, que durante meses fazia pequenos trabalhos: entregava encomendas, levava recados, trazia lenha, consertava o fogão, e, de repente, aparecia na rua gritando, esmurrando o chapéu, rasgando a camisa, dando pontapés na parede. Seu maior inimigo era o chapéu, que ele golpeava de todos os modos, gritando: animal, animal. Helena não comenta a história, ela quer saber por que Jonas matou Marcos. A história verdadeira. Jonas tergiversa. Marcos poderia ter cometido um ato irracio- 
nal, irrefletido, espontâneo, por mais abjeto que fosse... quem o condenaria?

Jonas sugere que haveria uma intenção de furto da parte de Marcos. Isso e a intenção de silenciá-lo, porque Jonas também conhecia algo do passado de Marcos que o comprometeria. Helena pede a Jonas que conte alguma outra versão e ameaça partir.

Jonas conta que ele conhecia Ana, ainda da Europa. Antes do encontro deles no Brasil. Conheceu Ana logo depois da guerra e também a Marcos, seu filho. Conta-lhe o que foram aqueles anos do após guerra: confusão, em meio à euforia para aqueles que haviam enfrentado a guerra e sobrevivido.

A luz principia a baixar. A noite se acentua... Jonas quer recomeçar tudo com Helena, zerar a relação, ir para outro lugar e começar do momento em que se conheceram.

A culpa não é mais deste Jonas. "Por que devo carregar uma culpa se já não é minha, se é de ontem, de anteontem, se é culpa de um dia que foi, já não é? ( p. 39)

Helena insiste que quer a história verdadeira. Jonas pede para ela pegar a sacola de couro na cômoda, que contém uma navalha, um revólver, uma corda, alguns frascos, ampolas. Jonas diz que tinha o material à mão porque poderia ser-lhe útil. Falta o punhal, que encontraram no corpo de Marcos.

Helena está saindo, quando chega Ana, e impede a saída, afirmando que vinha para morar com eles, já que Marcos estava morto e ela não poderia trabalhar. A peça mescla, assim, o conflito de ideias permeado pelo existencialismo e a noção trágica de que a vingança deve se seguir a um crime. Termina, entretanto, numa nota de cinismo ao juntar perpetrador e vítima no mesmo espaço.

A peça conclui com a fala de Jonas, pedindo à empregada que recolhesse os pacotes de Ana e que preparasse um quarto, pois ela a partir daquele instante iria morar na casa. E, para marcar a continuação dos hábitos de vida, em eco, a frase final:

Jonas: “Depois, pode servir o chá, Júlia.” (p. 43)

O autor é econômico nas rubricas, que são essencialmente descritivas, podendo indicar a marcação no palco. Quando respeitadas, elas ora conduzem a encenação segundo os moldes pretendidos pelo autor, ora estimulam a imaginação do leitor, mantendo um hábito das narrativas literárias. A partir daí, ori- 
6. SARTRE, Jean Paul. $O$

Existencialismo é um Humanismo, 1987, p. 6.

7. Ibidem, p. 7. gina-se uma dupla possibilidade de fruição do texto teatral: aquela que se efetiva pela via da encenação, o "teatro" propriamente dito, e aquela que se exerce pela leitura do texto dramático, na qual se percebem melhor suas características de narrativa.

A forma, debruada em longas falas filosóficas, é um lugar em que se podem divisar aspectos histórico-culturais da peça. A interferência do Existencialismo sartreano - filosofia surgida após a Segunda Guerra Mundial - é nítida na composição do texto de Rawet e na configuração de seu personagem protagonista.

O filósofo francês Jean-Paul Sartre (1905-1980) não escreveu apenas obras filosóficas, mas também ensaios, romances e peças de teatro. Em sua obra de caráter existencial, Sartre não deu uma importância excessiva ao problema religioso, pois não estava preocupado em discutir acerca da existência ou não existência de Deus. Antes, sua filosofia consiste em colocar o homem como responsável por todos os seus atos. Lançado num mundo sem justificativa, o indivíduo projeta-se no futuro, escolhe um sentido para sua vida, já que ela não possui um sentido a priori. Desta forma, o existencialismo de Sartre está inteiramente estruturado no fato de que a existência humana precede sua essência, e esta é construída através da liberdade responsável que o homem manifesta ao escolher sua própria vida. Nada, nem mesmo Deus, pode justificar o homem ou retirá-lo de sua liberdade total e absoluta, ou ainda salvá-lo de si mesmo.

Dizer que a existência precede a essência não é simplesmente suprimir Deus e negar a natureza humana em função da realidade humana. Dizer que a existência precede a essência é colocar o homem como um nada lançado no mundo, desprovido de uma definição. O homem surge no mundo e, "de início, não é nada: só posteriormente será alguma coisa e será aquilo que ele fizer de si mesmo". ${ }^{6}$ Ora, isso implica também o fato de que o homem só se faz num constante projeto, num incessante lançar-se no futuro. Somente assim o homem irá se definir como ser existente e consciente de si mesmo.

O existencialismo impõe ao homem a inteira responsabilidade no exercício de suas ações. Ao escolher sua vida, o homem também escolhe todos os homens. O valor de sua escolha é determinado pelo fato de que ele não pode escolher o mal. Nas palavras de Sartre: "o que escolhemos é sempre o bem e nada pode ser bom para nós sem o ser para todos". ${ }^{7}$ A imagem que moldamos de nós deve servir, em última instância, para todos os homens. Nesse sentido, o homem não é só responsável por si, mas também pela humanidade inteira.

Sendo assim, o existencialismo ateu de Sartre busca manter sua coerência atribuindo ao homem o compromisso de 
construir a sua própria essência. Lançado no mundo sem perspectivas, o homem determina sua vida ao longo do tempo, e descobre-se como liberdade, ou seja, como escolha de seu próprio ser no mundo. Ao falar da condição do homem, Sartre relaciona-o com a angústia, o desamparo e o desespero. Mas o que significa definir o homem nestes termos?

A angústia consiste simplesmente na descoberta de que o homem, quando escolhe, não é apenas o legislador de si mesmo, mas alguém que, ao mesmo tempo, escolhe a si mesmo e a humanidade inteira. O homem que descobre isso não consegue escapar de sua total e absoluta responsabilidade, que gera o sentimento original de angústia. Por isso é o próprio homem quem determina o valor de sua escolha, pois ele tem o constante dever de se perguntar: "o que aconteceria se todo mundo fizesse como nós?" Assim, a ação do homem, vista como a escolha constante de seu destino, é propriamente constituída por angústia.

Ao se referir ao desamparo, Sartre quer simplesmente dizer que "Deus não existe e que é necessário levar esse fato às últimas consequências". 9 Desamparo significa que o homem não possui nada a que possa se segurar, nem dentro nem fora dele; não existem bases para direcionar suas ações, a não ser sua liberdade e responsabilidade. Não existem valores eternos preestabelecidos que impeçam o homem de agir, nenhuma justificativa ou desculpa que o retire de sua escolha. Em qualquer situação, somos nós que escolhemos, subjetivamente, aquilo que provém de nossa própria vontade. O homem está só: “o desamparo implica que somos nós mesmos que escolhemos o nosso ser. Desamparo e angústia caminham juntos”. ${ }^{10}$ Não obstante, o desespero está ligado ao fato de que o existencialista não espera nada de um mundo transcendente. Se o desamparo é ausência de Deus, o desespero é não esperar por ele. As circunstâncias, deste modo, não podem servir como evasivas para nossos atos, nem como subterfúgios para nossos fracassos. Desespero: o que torna nossa ação possível é apenas a nossa própria vontade. Por isso Sartre escreve: "o homem nada mais é do que o seu projeto; só existe na medida em que se realiza; não é nada além do conjunto de seus atos, nada mais que sua vida". ${ }^{11}$ Projeto, liberdade, responsabilidade e existência que escolhe sua essência são termos constantes na obra de Sartre. Assim, podemos dizer que é inerente à condição do homem sua situação autêntica de angústia, desamparo, desespero.

Para Sartre, o absurdo do mundo é absoluto por sua constante possibilidade, isto é, tudo é gratuito: a vida humana não tem sentido algum, e para superar este caráter contingente da existência, o homem inventa Deus. Cabe exclusivamente ao homem dar um sentido à sua vida.
8. Ibidem, p. 7.

9. Ibidem, p. 8 .

10. Ibidem, p. 12

11.Ibidem, p. 13 
12.BEAUVOIR, Simone de. $A$ Cerimônia do Adeus, 1981, p. 591.

13.Cf. LEVI, Primo. Os afogados e os sobreviventes, 1990 , pp. 19-20.
A contingência faz do homem um ser solitário, que conta somente com sua subjetividade para agir. É pura ilusão acreditar que a vida humana possui um sentido dado por Deus. A única coisa que a vida oferece ao homem é sua própria liberdade, pois já que a vida não possui um significado preestabelecido, só podemos contar com nossa solidão, nossa absoluta individualidade. "A ausência de Deus era visível em todos os lugares. As coisas estavam sós, sobretudo o homem estava só. Estava só como um absoluto". ${ }^{12}$ Se Deus não existe, somente o homem pode decidir, sozinho, o melhor caminho para as escolhas que determinarão sua vida e sua essência.

O percurso feito até aqui permite observar que a afirmação de Sartre acerca da condição humana perpassa toda a sua obra, e se resume no fato de o homem ser um Deus fracassado, pois se projeta na realização de uma síntese impossível. Desta forma, a recusa de Deus, ainda que pouco evidente, está presente em todo seu pensamento.

Retornando à peça de Rawet, nota-se que o Existencialismo marca presença na fala do protagonista e nos traços que o compõem. O vazio de Deus, a solidão, a defesa da liberdade de escolha do próprio destino, o sem-sentido da vida pautam a conduta de Jonas, ao mesmo tempo em que o palco se torna o espaço alegórico e fantasmático da História, destituída, no entanto, das imagens externas, sempre subjetivadas. Assim, a Segunda Guerra, episódio que une (e separa) todos os personagens, é elíptica, mantém-se entre parênteses, subentendida, aludida no modo de ser de cada um, pois ninguém passa por ela impunemente. A ideia de confinamento e a incapacidade de troca intersubjetiva estão marcadas no espaço único em que se desenvolve a peça, nas falas longas, repetitivas e nos silêncios.

Todos os personagens são judeus, ainda que não se saiba o que isso significa. Todos passaram por campos de concentração e sobreviveram. Um deles, o protagonista, colaborou com os alemães em troca de sua sobrevivência. Ele se insere, assim, naquilo que Primo Levi chamou de "zona cinzenta", em seu livro Os afogados e os sobreviventes.

O autor dedica o segundo capítulo deste livro para discutir a facilitação da história quando ela evita os meios tons e a complexidade; neste caso, ela reduz a torrente de acontecimentos humanos aos conflitos, e os conflitos aos duelos, à oposição nós e eles. Não era simples a rede de relações humanas no interior dos Lager, não se podia reduzi-la a dois blocos, o das vítimas e o dos opressores. Muitos sobreviventes lembram o prisioneiro funcionário, que ao invés de lhes pegar a mão, tranquilizá-los, ensinar-lhes o caminho, se arroja sobre os recémchegados, gritando numa língua desconhecida, golpeando-lhes o rosto. Ele quer domá-los, quer apagar a centelha de dignidade que eles ainda conservem e que ele perdeu. ${ }^{13}$ 
Por que surge a "zona cinzenta"?

A zona cinzenta apresenta contornos mal definidos, que ao mesmo tempo separam e unem os campos dos senhores e dos escravos. Sua estrutura interna é complexa, a ponto de confundir nossa necessidade de julgar. A área do poder quanto mais estreita, mais precisa de auxiliares externos. $\mathrm{O}$ nazismo não podia prescindir deles, pois seu propósito era manter o poder no interior da Europa subjugada e alimentar as frentes de guerra que enfrentavam a resistência crescente dos adversários. Os colaboradores que provinham do lado inimigo tornam-se indignos de confiança, pois traíram uma vez e poderão trair outras. A eles são relegados os trabalhos sujos e de comprometimento crescente, de modo a contraírem com os mandantes um vínculo de cumplicidade, que os impede de voltar atrás. Do ponto de vista dos nazistas, entende-se a abertura para a participação de colaboradores. Mas o que movia os colaboradores?

Segundo Levi, quanto mais feroz a opressão, tanto mais se difunde entre os oprimidos a disponibilidade de colaboração com o poder. Essa disponibilidade é matizada por nuanças e diferenças infinitas: "terror, engodo ideológico, imitação barata do vencedor, ânsia míope por um poder qualquer, /.../ covardia, e até lúcido cálculo dirigido para escapar das regras e da ordem imposta." ${ }^{14}$ Diante de casos humanos como esses, reflete o autor, "é imprudente precipitarse emitindo um juízo moral. Deve estar claro que a máxima culpa recai sobre o sistema, sobre a estrutura mesma do Estado totalitário"15. É dificil avaliar a participação dos colaboradores, mas se a condição de vítima não exclui a culpa, e esta é objetivamente grave, Levi ressalta que não há tribunal humano ao qual atribuir sua avaliação.

Jonas, o protagonista da peça de Rawet, é um colaborador que se defende argumentando que aquele que cometeu o crime está no passado, permaneceu preso à transgressão. Por mais que o ato não possa ser julgado, fica a pergunta: é possível existir semelhante experiência moral sem culpa? Não será a experiência da culpa aquela que tira o homem da banalidade do mal e o devolve à ação transformadora de si mesmo e do mundo à sua volta?

Por outro lado, se o Existencialismo impõe ao homem a inteira responsabilidade no exercício de suas ações, existe um valor nessa escolha, determinado pelo fato de que ele não pode escolher o mal. Nas palavras de Sartre: "o que escolhemos é sempre o bem e nada pode ser bom para nós sem o ser para todos" ${ }^{16}$ A imagem que moldamos de nós deve servir, em última instância, para todos os homens.

Uma saída para Jonas seria reexaminar o próprio passado e sentir-se culpado, e assim circunscrever sua liberdade de escolha a um tempo definido, podendo se sentir como outro de si mesmo, conforme se autoproclama. Entretanto, ele
14.Ibidem, p. 21.

15.Ibidem, p. 22.

16.SARTRE, Jean Paul. O

Existencialismo é um Humanismo, 1987, p. 7. 
mantém em segredo sua aliança com o nazismo e continua vivendo num mesmo registro, até que surgem as testemunhas desta conduta. Esta ganha visibilidade aos olhos de Helena após algumas peripécias e principalmente após o assassinato de Marcos, que invade a casa de Jonas, armado para matá-lo. Os dois são antípodas: Marcos é espontâneo e pretende fazer justiça com as próprias mãos, matando um homem que ele considera culpado, enquanto Jonas é maquinador. Ele estava preparado para um possível acerto de contas com o passado, o que se pode depreender de seu arsenal de objetos para matar e provocar a própria morte. Mas sai ileso e acaba por apunhalar Marcos. Jonas tenta forjar um motivo para a morte de Marcos, mas Helena insiste em querer saber a verdade, verdade que se mantém ambígua na peça: o que Ana e Marcos sabem a respeito da atuação de Jonas? É a verdade o que Jonas conta para Helena a propósito de sua colaboração com o inimigo? Ele conhece as atividades de Marcos? Por que este foi procurado pela polícia? Será que ele foi mesmo procurado pela polícia?

O final da peça surpreende, pois Helena descobre, em Jonas, um homem com quem não quer mais conviver. Está de partida e é impedida por Ana, que está chegando à casa do casal, para ficar. Sem o filho, já velha, ela se justifica dizendo que não tem como se manter, nem para onde ir. Há um peso irônico na inversão de sinais da última cena: a vítima opta por conviver com aquele que atuou do lado do perpetrador, embaralhando ainda mais a rede intrincada que perfaz a "zona cinzenta”. Suspende-se a vingança em nome dos mortos e sacrificados e os três (Helena permanece ou parte?) se juntam para viver uma vida em comum.

Talvez possa se afirmar que há um duplo padrão que rege a peça de Rawet: ele está disposto a aceitar os dados relacionados à Shoá na história, mas impõe suas predileções metafísicas sobre suas personagens, mesmo quando essas predileções violam as necessidades psicológicas nelas criadas por sua participação na história. O resultado é que o movimento da história, que fomos preparados para encarar como rigorosamente objetivo, assume a liberdade, e mesmo o capricho da subjetividade, enquanto o comportamento dos personagens, que deveria se orientar para as possibilidades da vontade humana, assume a aura da ambiguidade. Ainda em relação à Shoá, o compromisso de guardar a memória dos mortos e o empenho em evitar a repetição do ocorrido também corroboram para alimentar o duplo padrão: de um lado, Ana fala em nome dos que passaram pelo campo de concentração:

Ana: "/.../ Eles, os que ficaram de fora, podem e devem esquecer o que nos aconteceu. (Pausa) Mas nós?...” (p. 12)

De outro lado, o empenho de Jonas é o de esquecer, pois 
ele passou pelo campo de concentração, mas colaborou com o perpetrador.

\section{É preciso lembrar ou esquecer?}

Retomando o conto hassídico do coxo contado por Jonas, pode-se afirmar que o mestre foi destituído, inaugurando um espaço de orfandade, de vazio. Deus, o pai, o rabi, qualquer autoridade moral, não há mais exemplos a serem seguidos, instaurando-se a desordem, como única possibilidade. Daí o título da peça apresentar o artigo definido, fazendo eco à univocidade dos caminhos, não obstante a possibilidade infinita de cada um poder escolher o seu próprio destino.

Quanto à noção de culpa, o domínio de um passado retornado na forma de pesadelo sobre um presente não redimido só poderia ser rompido pela força analítica de uma memória que presentificasse a história em sua revisão moral. Não é isso o que ocorre, mas uma cristalização de ideias que se tornam automáticas, instrumentalizadas, alijando as posições que contrariem o status quo estabelecido. A linguagem torna-se pouco nuançada, repetitiva, impotente para se subtrair de um cerco de morte, contrastado pelo mundo exterior, representado por ecos carnavalescos, em que dança, música e canto apontam para outra história e outra esfera de existência. De um lado, há a presença do estrangeiro e nele a relação problemática do judeu frente a si mesmo, frente aos demais e frente ao que é ser judeu; de outro, o Brasil idealizado e apresentado simbolicamente na apoteose do Carnaval, sempre fora, num território apenas tangível pela doméstica que faz o trânsito entre o espaço interno e o externo.

Helena, a companheira de Jonas, tenta trazer, na primeira cena da peça, o carnaval para dentro da casa, numa imitação dos passos da negra da escola de samba. Mas, retomando o conto hassídico, esta não era sua mestra e ela não alcança imitá-la:

Helena - No caminho vim observando uma negra imensa, gorda, com os olhos meio fechados, umas canelas finas para tanto peso. Como pisava manso! (Imita-lhe os gestos) De leve! Como girava as nádegas! Os braços pareciam mover-se com ares de dama de uma corte perdida, na mais requintada dança de salão... (Cantarola) Tem pena de mim... tem... Tem pena da minha dor... tem...

Jonas - Helena!

Helena - (Cai em si. Sorri) Apesar do contágio, nunca poderia atingir o mesmo requinte. Seria uma contrafação ridícula.

Jonas - Nenhum de nós o conseguiria. E os requintados somos nós... (Amargo) animais enfarpelados com uma carapaça de cultura que se funde ao primeiro contágio com uma situação limite. Então somos mais bárbaros, e 
sem ingenuidade, e sem pureza, e sem orgulho sequer de sermos bárbaros. (Controla-se) Um pouco de chá, Helena?

Do ponto de vista da eficácia teatral pode-se dizer que o final da peça não só surpreende, mas se constitui como uma espécie de deus ex machina, pois não há um suporte convincente que o justifique. $\mathrm{O}$ autor resolveria melhor seu argumento se conduzisse ao extremo a relação construída entre homem e mulher, tomando como referência a Segunda Guerra Mundial. A partir do momento em que Ana e Marcos entram em ação, marcando a necessidade de vingança fundamentada na tragédia, cria-se um embate com o Existencialismo, pondo em questão os imperativos morais, num pano de fundo em que ao homem cabe o direito de escolha de seu próprio destino. Como o embate é complexo, o autor junta as partes numa virada surpreendente, que cabe, por exemplo, nas peças de fundo melodramático de Nelson Rodrigues, mas não na peça em pauta.

Se radicalizada a primeira parte da peça de Rawet, teríamos um resultado próximo a Huis Clos (em português, Entre quatro paredes), de Sartre. Nela, este autor prende até a morte quatro personagens num espaço fechado e intransponível. Aí, cada personagem é carrasco do outro, alavancando a exposição do que há por trás de cada um. Assim, o autor questiona a condição humana, suas crenças e ações, enquanto releva a linha tênue que separa o ato bom e o ato mau praticado por seres humanos.

O enfrentamento entre Jonas e Helena, se explorado em sua radicalidade, traria para a superfície cênica as subjetividades no tempo presente da ação, escapando da necessidade de trazer o passado através do testemunho de outros personagens, alcançando, assim, a contração da ação e do drama. O intercurso do deus ex machina quebra o andamento da peça que procura recuperar sua unidade na pirueta da fala final, retomando um mote que pontua a peça e atribui autoridade ao protagonista recolocado ironicamente em seu lugar.

Jonas: "Depois, pode servir o chá, Júlia." (p. 43)

Se há um esforço na reflexão de Primo Levi em enxergar a História para além do binômio amigo-inimigo, vítima-algoz, a peça retoma-o, ao se assentar na oposição nós-eles, em que o estrangeiro, o não-nacional, está inserido num lugar intransponível. Com ela, Rawet recupera o tema do estrangeiro, do judeu 
imigrante e/ou egresso do campo concentração e os esforços despendidos para sua difícil adaptação no Brasil. No intervalo entre dois espaços, duas culturas, em meio à orfandade de Deus e à orfandade social, não é fácil apontar quem é o vilão da história. Isso porque o autor conduz o leitor/expectador a pensar a partir de perspectivas diversas, aproximando-o ao território da ambiguidade, isto é, da aceitação permanente de outros sentidos. Se o autor constrói a peça num tempo e numa circunstância que oferecem poucas saídas ao personagem, por outro lado, ele induz o leitor a pensar a questão de diferentes ângulos, afastando as posições categóricas e contundentes. Um caminho estreito para um entendimento amplo. 


\section{Referências}

ABBAGNANO, Nicola. A Sabedoria da Filosofia. Petrópolis, RJ: Vozes, 1989.

BAUMAN, Zygmunt. Modernidade e Holocausto. Rio de Janeiro: Jorge Zahar, 1998.

BEAUVOIR, Simone de. A Cerimônia do Adeus. Trad. Rita Braga. Rio de Janeiro: Nova Fronteira, 1981.

BETTONI, Rogério A. Comunicação apresentada na V Semana de Filosofia, FUNREI, 1999, ISSN 1749 8457, Copyright (C) 1997-2009. http://criticanarede.com/termos. html.

BORNHEIM, Gerd A. Sartre: Metafísica e Existencialismo. São Paulo: Perspectiva, 1984.

GAGNEBIN, Laurent. La Foi. In: Connaître Sartre. Paris: Resma, 1972.

GUINSBURG, Jacó. Diálogos sobre teatro. Org. Armando Sérgio da Silva. São Paulo: Edusp, 1992.

GUINSBURG, Jacó; BARBOSA, Ana Mae (orgs). O Pósmodernismo. São Paulo: Perspectiva, 2005.

RAWET, Samuel. Contos e Novelas Reunidos. Org. André Seffrin. Rio de Janeiro: Civilização Brasileira, 2004.

JEANSON, Francis. Sartre. Trad.: Elisa Sales. Rio de Janeiro: José Olympio, 1987.

LEVI, Primo. Os afogados e os sobreviventes. Trad. Luiz Sergio Henriques. Rio de Janeiro: Paz e Terra, 1990.

PRADO, Paulo. Retrato do Brasil: ensaio sobre a tristeza brasileira. 3o edição. São Paulo: Duprat-Mayença, 1929

NOGARE, Pedro Dalle. Humanismos e Anti-Humanismos. Petrópolis, RJ: Vozes, 1988.

MOSTAÇO, Edélcio O teatro Pós-moderno, In:

GUINSBURG, Jacó; BARBOSA, Ana Mae (orgs.). O Pósmodernismo. São Paulo: Perspectiva, 2005.

SARTRE, Jean-Paul. A Náusea. Trad. Rita Braga. Rio de Janeiro: Nova Fronteira, 1986.

-. As Moscas. Trad. Nuno Valadares. Lisboa: Editorial Presença, 1986. 
-. As Palavras. Trad. J. Guinsburg. Rio de Janeiro: Nova Fronteira, 1984.

-. Diário de uma Guerra Estranha: Novembro de 1939, Março de 1940. Trad. Aulyde Soares Rodrigues. Rio de Janeiro: Nova Fronteira, 1983.

—. O Diabo e o Bom Deus. Trad. Maria Jacintha. São Paulo: Difusão Européia do Livro, 1965.

-. O Existencialismo é um Humanismo. Trad.: Rita Correia Guedes. São Paulo: Nova Cultural, 1987. (Os Pensadores).

-. O Ser e o Nada: Ensaio de Ontologia Fenomenológica.

Trad. Paulo Perdigão. Petrópolis, RJ: Vozes, 1997.

-. Sursis: Os Caminhos da Liberdade, 2. Trad. Sérgio

Milliet. Rio de Janeiro: Nova Fronteira, 1983.

SZONDI, Peter. Teoria do drama moderno (1880-1950). Trad.

Luiz Sérgio Repa. São Paulo: Cosac \& Naify, 2001. 
17. "Nós vivemos num mundo em que as pessoas querem se comunicar de uma forma urgente e terrível. Comigo aconteceu também isso. Só poesia já não me bastava. [...] Então procurei o teatro [...]". Reportagem de Regina Helena para o Correio da Manhã (Sucursal de São Paulo), 27.12.1969, apud. VINCENZO, Elza Cunha de. O Teatro de Hilda Hilst, 1992

* Agradeço a Gilberto

Figueiredo Martins, que me apresentou a peça $A s$ aves da noite, de Hilda Hilst, num momento anterior a sua publicação.

18. ROSENFELD, Anatol.

"O teatro de Hilda Hilst",

"Suplemento Literário", $O$

Estado de S. Paulo, 21.01.1969.

19. HISLT, Hilda. Teatro completo, 2008, pp. 229-298.

20. Cf. Berta Waldman, La Shoá en la literatura brasileña: una pequeña gramática, 2006, pp. 103-123.

\section{II. “Aves da Noite: sobrevoando Auschwitz"}

A produção dramatúrgica de Hilda Hilst (1930-2004) circunscreve-se ao período que vai de 1967 a 1969. Por que escrever para o teatro, quando já era um nome importante na prosa e na poesia brasileira? A verdade é que a distinção entre poesia e teatro, na obra de Hilst, em certo sentido se esvai, já que a poesia estende-se teatro adentro, tornando-o espesso e de difícil apreensão, embora, segundo consta, ${ }^{17}$ a autora teria sido levada a experimentar o gênero em busca de uma comunicação mais imediata com o público, comunicação que sua poesia não estabelecia. O ingrediente poético de seu teatro corrobora para acentuar mais os problemas humanos do que os político-sociais de seu tempo, atribuindo-lhes verticalidade e contundência. Apesar disso ou por isso, o teatro de Hilda Hilst foi pouco encenado e mereceu raros textos da crítica, sendo o estudo de Anatol Rosenfeld talvez o único que o aborda em seu conjunto. ${ }^{18}$ Para o crítico, a dificuldade de encenação das peças de Hilst residiria no teor intensamente poético de sua prosa e também no complexo universo ficcional que elabora, ao subtrair praticamente as balizas do tempo, fazendo as personagens tipificadas se moverem num espaço que, em geral, funciona como símbolo ou como alegoria de algo que não é explicitado ao espectador.

Num período em que o interesse do público e dos encenadores se voltava principalmente para temas políticos relacionados de modo direto à situação brasileira, causava estranhamento essa forma oblíqua de expressão permeada sempre de sensibilidade visual e plástica.

Em “As Aves da Noite” (1968) ${ }^{19}$, peça que é objeto de minha análise, Hilda Hilst mostra-se precursora no que diz respeito à matéria escolhida. Sua peça passa-se em Auschwitz e se refere ao Holocausto, num momento em que poucos o tematizavam na literatura brasileira. ${ }^{20} \mathrm{~A}$ peça parece apontar para dois lados distintos, porém concomitantes: ao referir-se à grande ferida não cicatrizada da Segunda Guerra Mundial, a peça alude também, na minha leitura, à ditadura brasileira. 
Ao mesmo tempo que Hilda Hilst, o escritor imigrante da Polônia, Samuel Rawet, ${ }^{21}$ que integrou o grupo Café da manhã criado por Dinah Silveira de Queiróz, do qual participaram também Fausto Cunha, Renard Perez, Fábio Lucas, Nataniel Dantas e outros, interessados em dramaturgia, escreveu peças como "Os Amantes", em 1957, que chegou a ser encenada no Teatro Municipal do Rio de Janeiro. Já “O lance de dados", peça inédita, sobre um colaborador judeu durante a Segunda Guerra Mundial, que vive no Rio de Janeiro, não foi representada. Samuel Rawet antecede Hilda Hilst no tratamento do Holocausto em contos. ${ }^{22}$ Isso se deve, com certeza, ao fato de ele estar diretamente implicado nesse episódio histórico, enquanto judeu que viveu o antissemitismo na Europa do Leste, tendo sido constrangido a imigrar com a família para o Brasil.

Para criar uma perspectiva paralela, menciono alguns dados sobre o teatro e o Holocausto na Alemanha neste mesmo período. Helmut Galle, ${ }^{23}$ levantando algumas hipóteses dos motivos que retardaram a presença do Holocausto na produção teatral alemã, pondera que o romance e o gênero épico parecem ser mais adequados a tratar do tema, pois o discurso do narrador permite a multiplicação de níveis temporais, a integração de comentários, dúvidas e correções. O drama, ao contrário, exige o diálogo: o jargão dos perpetradores precisa contracenar com a fala das vítimas e o silêncio dos mortos. Como forjar algum conflito a ser solucionado mediante a catarse? O caráter coletivo do assassinato, o sem sentido do processo negam-se a uma representação exemplar no cenário. Entretanto, Galle destaca três encenações teatrais importantes do Holocausto na década de 60, na Alemanha: as de Rolf Hochhuth, Peter Weiss e Heinar Kiphardt. A supressão sistemática do homicídio em massa do discurso público, na memória coletiva da sociedade, clamava, depois de décadas de latência, por discussão. A geração dos filhos requeria esclarecimentos sobre a ação de seus pais e mães.

A grande ressonância das peças se deve ao fato de os autores terem levado o tema a discussão pública. A função das peças não era entender o genocídio, mas insistir no fato de que o genocídio tinha sido organizado por alemães, que isso havia sido feito com extrema brutalidade e que todos os culpados não só não haviam sido responsabilizados, como se podia encontrá-los nos lugares decisivos da indústria, do Estado e da vida pública alemã. ${ }^{24}$
21. A obra de Samuel Rawet mereceu organização e republicação recente. Ver Contos e Novelas Reunidos, 2004.

22. Cf., por exemplo, o conto "O Profeta" desse autor, que data de 1956. Em Contos e

Novelas Reunidos, 2004..

23. GALLE, Helmut. Sobre la representación del holocausto en el drama alemán. El callejón sin salida del teatro documental, 2003, pp. 79-95.

24. Cf. Helmut Galle, 2003. 
25. HILST, Hilda. "As aves da noite", In: Teatro Completo, 2008, p. 237. [As citações subseqüentes entre parêntesis correspondem a esta edição].

26. HOCHHUT, Rolf. O vigário, 1965, pp. 275-276.

\section{2. "As aves da noite" (1968)}

As circunstâncias que levaram ao que aconteceu no "Porão da Fome”, espaço em que se passa a peça, em Auschwitz, no ano de 1941, estão indicadas na abertura do texto:

Do campo de concentração fugiu um prisioneiro. Em represália os SS, por sorteio, condenaram alguns homens a morrer no Porão da Fome. Figurava entre os sorteados o prisioneiro n. 5659, que começou a chorar. O padre católico franciscano Maximilian Kolbe, prisioneiro n. 16670, se ofereceu para ocupar o lugar do n. 5659. Foi aceito. Os prisioneiros foram jogados numa cela de concreto onde ficaram até a morte. O que se passou no chamado "Porão da Fome" ninguém jamais soube. A cela é hoje um monumento. Em 24 de maio de 1948, teve início em Roma, o processo de beatificação do Padre Maximilian Kolbe. ${ }^{25}$

É também ao Padre Maximilian Kolbe, internado $\mathrm{n}^{\underline{a}}$ 16.670 em Auschwitz, que Rolf Hochhut dedica seu livro, $O$ vigário. No corpo do livro consta que o Padre Maximilian Kolbe, franciscano, nasceu em Lodz, em 1894. ${ }^{26}$ Antes da guerra servira como missionário no Japão. Morreu em agosto de 1941, na "cela da fome" de Auschwitz, nas seguintes circunstâncias:

Um de seus companheiros de cativeiro evadiu-se do campo, embora tal ação fosse punida com a condenação de dez outros prisioneiros à morte pela fome. Foram, pois, sorteados ao acaso dez homens do mesmo bloco do fugitivo, entre os quais F. Gajowniczek, casado e com filhos. Este começou a chorar. Kolbe deu então um passo à frente e pediu para morrer no lugar dele, dando como razão que era já inapto para o trabalho. Embora se tratasse evidentemente de um subterfúgio, parece que os próprios SS se impressionaram. Assim, o detido 16.670 foi autorizado a entrar na "cela da fome", em vez do nª 5.659 [que sobreviveu à guerra]. Os prisioneiros foram amontoados nus numa cela de concreto, desprovida de janelas, onde nem água recebiam. A cela é hoje um monumento. O Padre Maximilian confortava seus camaradas agonizantes. $\mathrm{O}$ prisioneiro Borgowiec, cuja tarefa era fazer a limpeza das celas da morte, declarou que os homens das SS não conseguiam fitar Kolbe nos olhos. Certa ocasião, ao retirarem os corpos dos mortos, gritaram-lhe: “Olhe para o chão e não para nós!" Para eles, o Padre Kolbe estava morrendo lentamente demais, ou então, talvez a conduta dele os obrigasse a dar o golpe de misericórdia, pois acabaram por lhe aplicar uma injeção. Um documento afirma que ele foi o último a morrer, outro documento indica que ainda estavam presos dois prisioneiros quando ele morreu. 
Hilda Hilst baseia-se nos dados biográficos de Kolbe para montar sua peça. Nela, cinco prisioneiros vão para a cela da morte. Quando a peça inicia, eles já se encontram ali há algum tempo. As personagens são: Estudante, Poeta, Joalheiro, Carcereiro e Padre.

A peça inicia com o Estudante, seguido do Joalheiro, instando o Poeta a continuar a dizer um poema. "Isso pode nos aliviar", diz o Joalheiro.

O poema trata de um corpo morto que sonhou, amou e pertence já ao grande tempo sem fim. De outro lado, uma história é contada pelo Estudante: tem gente que cria o gato desde pequeno em plena escuridão e depois o solta numa manhã de sol. Para o padre Maximilian, única personagem nomeada na peça, o medo é o responsável pelos comportamentos absurdos. Além desses relatos, a peça é "costurada" por histórias e poemas, que funcionam como bricolagem, remetendo sempre para outro tempo e outro espaço. Assim, desde a abertura, a linguagem remete à linguagem (poesia, narrativa, canção), e gera dispersão, distância, atraso e suspensão dos sentidos. Esses textos circulam concomitantes na superfície do enredo, funcionando menos como sua interpretação, e mais como componentes de uma técnica de deslocamento, que faz o contraponto da espera da morte, de certo modo preenchendo-a.

Merece destaque o relato do Estudante de Biologia que gira em torno de uma experiência feita com um falcão, obrigado a engolir um tubo de metal fechado nas duas extremidades, com um pedaço de carne dentro, e uma tela de arame selando o cilindro, para deixar passar o suco gástrico. Depois de um tempo, o falcão vomita o tubo já sem a carne que se dissolvera. Com a dimensão da vida humana circunscrita ao corpo, cria-se uma analogia entre a experiência com o falcão e os corpos dos prisioneiros na cela. Eles iniciam uma discussão:

"Nós somos iguais àquela carne dos tubos", diz o Carcereiro. "Somos feitos de células carnívoras" (p.252). Afirmação contestada pelo padre Maximilian: "Nós somos feitos à imagem e semelhança d'Aquele". "Mas nós temos alma". (p. 252)

Com esse relato fixa-se um eixo importante da peça, que impulsiona a discussão metafísica sobre o que é o ser humano e seu destino. A partir desse momento, vêm à tona, de forma contundente, os temas dominantes na poesia e no teatro de Hilda Hilst: as perguntas sem resposta sobre a existência do mal, sobre o mistério de Deus, sobre o sentido da vida, sobre a morte. Também circulam questões voltadas ao corpo, à alma, à libido. Esses homens que discutem, por sua vez, estão numa cela, incrustada numa forma cilíndrica, semelhante àquela engolida pelo falcão. O cenário da peça é indicado pela autora: 
27. Cf Jeanne Marie Gagnebin. Lembrar escrever esquecer, 2006, pp. 76 e segs. Leib reenvia ao mesmo radical que Leben (vida), enquanto Körper remete à forma de cada corpo.
Cilindro de altura variável, dependendo da altura do teatro. Altura do interior da cela, dentro do cilindro: $1,90 \mathrm{~m}$. $\mathrm{Na}$ cela, porta de ferro baixa, com pequeno visor. Janela à volta do cilindro recoberta de material transparente (arame, acrílico etc.) Cadeiras individuais à volta do cilindro, isoladas umas das outras por divisões. (p. 231)

Os cilindros imbricam-se, um contém o outro (mise en abyme), e multiplicam-se; a repetição das formas funciona como um sorvedouro, modo de aprisionar, impedimento para sair, avançar, ir em frente, situando o espectador isolado (cadeiras separadas por divisões) cara a cara com o horror, o sofrimento, o aniquilamento físico, a morte. Há uma insistência na corporeidade do sofrimento. Sofrer remete ao corpo (Leib) no seu sentido mais originário de organicidade viva, bruta, pré-individual e pré-reflexiva. ${ }^{27}$

A situação vivenciada tem um cunho absurdo, pois as personagens estão trancadas por acaso, não sabiam que seriam sorteadas e punidas por um ato que não cometeram, que outro cometeu, transformando-as todas em culpadas. Assim, limitados ao espaço físico e ao seu corpo, não há mais como controlá-lo:

“Os homens começam a defecar.” (p. 254)

O Poeta insiste: "o que é o corpo?” (p. 255)

O Estudante lembra: "Ela me dizia que o corpo muitas vezes parece uma coisa independente da tua vontade" (p. 257) Ele, ainda, "se você repetir a palavra corpo muitas vezes [...] o corpo deixa de significar o teu corpo e toma a forma de alguma coisa volumosa e cinzenta, ali, à tua frente.” (p. 255)

Poeta: “O corpo é uma esplêndida organização.” (p. 255)

Maximilian: "O corpo é envoltório daquilo que está mais fundo, por isso...” (p. 256)

Poeta: "Eu sou meu corpo. Eu sou esta imundície que parece não ter fim.” (p. 256)

O mistério do corpo perecível aflora na peça, cuja ação vai se adensando, sem qualquer probabilidade de mudança, pondo em relevo a angústia da espera da morte. A tensão incorpora-se nessa espera estruturada num presente que é duração, apoiado em passados diversos, que vêm à tona através de relatos paralelos. Comportamentos e histórias distintas transparecem e interagem.

O número ímpar das personagens é centralizado pelo padre Maximilian ladeado por dois pares simétricos distintos: dois jovens - o Poeta e o Estudante, e dois velhos: o Joalheiro e o Carcereiro. Os jovens (um artista, o outro biólogo) a serem amparados falam de si como aqueles que desaparecerão. Já o Joalheiro que lida com pedras indestrutíveis ("eu amo as pedras”, p. 253) e o Carcereiro, que carrega as chaves de ferro 
que não lhe servem, entretanto, para sair da cela, apegam-se à matéria dura, tentando camuflar e recalcar a própria fragilidade. Essa disposição triádica pode sugerir elementos fulcrais do Cristianismo: a Santíssima Trindade ${ }^{28}$ composta por Deus pai, Deus filho e Espírito Santo, como também à cena da crucificação de Cristo. ${ }^{29}$

Apesar de distintas, as quatro personagens da peça coincidem num ponto: todas querem saber quem é Maximilian? Como entendê-lo?

"Poeta: (Para Maximilian. Exaltado) - Por quê? Por quê? Por que você escolheu esta nossa morte quando podia ter a vida? Ainda que fosse aquela... Era vida - Que força te conduziu para isso? Por quê?” (p. 245)

"Carcereiro: Ele a si mesmo se escolheu. Ele quis." (p. 246)

"Poeta: (A Maximilian) Como é que você pode? Fala!" (p. 246)

"Joalheiro: Maximilian, você é feito de carne?" (p. 247)

“Carcereiro: De ossos. Você não vê?” (p. 247)

"Estudante: de células carnívoras, como todos nós." (p. 247)

O SS ${ }^{30}$ introduz uma mulher ("uma bela judia") na cela e a obriga a cumprimentar com um "boa noite, porcos". Ela deve praticar sexo com todos. Em vez disso, ela canta. Em sua canção, o mundo é claro em oposição ao mundo escuro em que vive e atua no campo. Ela tem a função de limpar as câmaras de gás: "primeiro a gente limpa o sangue, as fezes. Depois separamos os corpos. Os corpos ficam agarrados. Os corpos como uma pirâmide toda feita de sangue...” (p. 264)

Enquanto os prisioneiros estão se aproximando da morte, o padre Maximilian molda-se, cada vez mais, à imagem de Cristo. Amar o próximo parece ser o seu aprendizado e inclui os SS como objeto de seu amor. A culpa e a inocência, o bem e o mal, o poder divino, são discutidos. Afinal, como Cristo, o padre ofereceu-se para morrer por outro homem.

O Poeta está morrendo e pede que lhe cantem uma música, pois é ela que o conduzirá para o amor, a luz (p. 38). Enquanto isso, a mulher tenta justificar-se.

"Mulher: Eu ponho a mão em todos aqueles corpos, mas sou inocente.” (p. 273)

"Qual o sentido da carnificina?” O Carcereiro pergunta (p. 275)

Em meio aos questionamentos metafísicos, ouve-se a voz de Hitler: "Ele é o reverso, você sabe? O reverso. O outro rosto de cada um de nós." (p. 279)

O Carcereiro pede um abraço do padre e começa a morrer. Fora, os soldados da SS estão estuprando uma mulher que está morrendo.
28. A Santíssima Trindade é um dogma da Igreja Católica, uma proposição teológica de crença obrigatória, definitiva e imutável. Assim, é absolutamente verdade, para todo cristão, a existência de um único e mesmo Deus, criador do céu, da terra e de tudo que nela existe. Sobre a Santíssima Trindade, o Concílio de Latrão (1215) assim se manifestou: "Firmemente cremos e simplesmente confessamos que apenas um é o deus Eterno, Verdadeiro, Imutável, Incompreensível, Onipotente e Inefável; Pai, Filho e Espírito Santo; três, certamente, mas uma só substância, uma só essência. O Pai não vem de ninguém, $\mathrm{O}$ Filho, apenas do Pai, e o Espírito Santo, de Um e de Outro, sem começo, sempre, e sem fim." Cf. Santo Agostinho, Confissões. Livro XIII, n.5: A Trindade Divina. In Os Pensadores, vol. IV, Santo Agostinho, Confissões e De Magistro. São Paulo: Abril Cultural, fev. 1973.

29. Cf. Evangelho de S. Lucas, 23:33.

30. SS são as iniciais, em alemão, de Schutz-Staffel, que significa "pelotão de proteção". Tratavase, no princípio, da guarda pessoal de Hitler, espécie de polícia particular que servia ao chefe e aos membros do partido nazista. Quando Hitler sobe ao poder, este grupo torna-se mais numeroso, passando às ordens de Henrich Himmler, constituindo uma espécie de estado dentro do Estado. São eles que se ocuparam principalmente dos campos de concentração e da eliminação dos judeus. Cf. Annette Wieviorka, Auschwitz expliqué à ma fille, 1999, p. 26. 
31. AGAMBEN, Giorgio. Homo sacer. El poder soberano y la nuda vida, 1998.
“O Joalheiro grita: Adonai! Claríssima morada!” (p. 290)

$\mathrm{Na}$ parte final da peça, Maximilian ganha dos SS uma coroa de arame farpado, e em torno dela os que ainda sobrevivem devem girar. Caminhar em círculo significa não chegar a ponto nenhum. É importante lembrar que o círculo compõe a figura do cilindro, representação do espaço cênico e também a forma do tubo de experiência ingerido pelo falcão, reiterando com a coroa a sua função: $o$ círculo aprisiona.

\section{3.}

No livro Homo sacer $^{31}$ Giorgio Agamben, discípulo de Michel Foucault (1926-1984) e leitor de Hannah Arendt (19061975), aponta para as profundas transformações ocorridas na cena política contemporânea com a instituição do que chama de biopolítica - o homem visado como corpo - e o surgimento do campo de concentração como paradigma do poder.

Há um movimento lento, mas claro, na História, em que se passa dos suplícios os mais cruéis - as humilhações públicas, as torturas praticadas para punir a alma e corrigi-la -, ao isolamento e trabalhos forçados. Foucault aponta para um deslocamento da noção de poder que se desdobra ao longo do século XIX, atingindo seu desenvolvimento máximo no início do século XX - o "poder disciplinar" que atua sobre as populações modernas em oficinas, quartéis, escolas, prisões, hospitais, clínicas, etc., com o propósito de produzir um ser humano que possa ser tratado como um corpo dócil.

Agamben, nesse livro, reivindica uma intensa revisão crítica de muitos dos pressupostos sobre os quais se sustenta nosso modo de compreender a modernidade e sobretudo suas estruturas político-estatais. O autor apresenta uma interpretação original de legados e heranças que forjaram os discursos da filosofia política de Aristóteles até a época dos campos de extermínio e da sociedade do espetáculo.

Pode-se dizer que a busca de Agamben é política e supõe mobilizar os recursos da crítica para impedir que as estruturas de dominação, as forças poderosas que hoje articulam a globalização, sejam as donas últimas de uma tradição convertida em máquina de exclusão e extermínio. Salvar o ideal emancipatório supõe desconstruir os fundamentos filosóficos e jurídicos que estão na base do estado moderno e, sobretudo, na definição da ideia de soberania. Não por acaso o autor se detém em entender o Holocausto da Segunda Guerra Mundial, momento em que a razão iluminista emancipada reduziu-se com sucesso 
à mera racionalidade instrumental da lógica da aniquilação. O autor oferece-nos em sua abordagem dos campos e do Holocausto uma compreensão abstrata do fato, aludindo menos a seus componentes históricos que a seu núcleo estrutural, de modo a poder estender, a partir de Auschwitz, sua interpretação de outros eventos de opressão no século XX.

O mesmo parece ocorrer com "As Aves da Noite", peça não-referencial, embora anuncie passar-se em Auschwitz. Esse dado, entretanto, não é suficiente para atribuir historicidade ao texto, que não conta com elementos que apontem para o campo polonês de extermínio nazista ou para a história da Segunda Guerra Mundial, tratando apenas do episódio que gerou a peça: a fuga de um prisioneiro e a represália dos SS que sortearam cinco homens, enclausurando-os até a morte por inanição. $\mathrm{O}$ que foi o nazismo fica fora, e é difícil determinar se a peça falha em sua construção e, neste caso, ao pretender fazer uma coisa a autora fez outra, ou se sua intenção foi realmente usar o cenário nazista para aludir à ditadura militar brasileira e a outras situações de tirania e barbárie.

"O que se passou no chamado Porão da Fome ninguém jamais soube. A cela é hoje um monumento. Em 24 de maio de 1948 teve início, em Roma, o processo de beatificação do Padre Maximilian Kolbe”. A peça tenta preencher o que nunca se soube, mas circunscreve-se a um plano estritamente subjetivo.

As cinco personagens mais a mulher, salvo Maximilian, não são nomeadas. Elas aglutinam tipos distintos, submetidos todos eles aleatória e absurdamente ao extermínio. Dada a impossibilidade apriorística de salvação (como salvar os condenados de um campo de concentração?), o andamento da peça não oferece surpresas, pois sabe-se de antemão que todos morrerão. A previsibilidade do enredo tem, no entanto, a contrapartida da surpresa nos variados tipos de relatos: poesia, canção, lembranças, enunciados pelas personagens, que trazem o passado ao presente, numa tentativa de subtraí-lo da sombra. Também no plano das personagens busca-se uma variedade que ambiciona abarcar um grupo representativo de tipos humanos, jovens e velhos, homem e mulher, arte, ciência e vida prática, judeus e cristãos. $\mathrm{O}$ foco na subjetividade lança o que é acontecimento para o escuro. Por que as personagens foram detidas pelos nazistas? Quais foram seus delitos? Pertencerão a alguma minoria? Serão judeus? A mulher introduzida na cela se des- 
32. "Com esta denominação deliberadamente vaga, "Esquadrão Especial" [Sonderkommand], era indicado pelos SS o grupo de prisioneiros aos quais estava confiada a gestão dos fornos crematórios." Cf. o cap. II "A Zona Cinzenta", de Os afogados e os sobreviventes, de Pimo Levi (1990, p. 26).

33. Cf. o trabalho de doutorado de Ariel Finguerman sobre a chamada "Teologia do Holocausto": "A Ortodoxia Moderna e o Holocausto", em andamento. BERKOVITS, Eliezer. With God in HellJudaism in the Ghettos and Deathcamps, 1979.

34. Cf. www.auschwitz.dk/ kolbe.htm e www.aish.com/ holocaust. culpa junto aos companheiros. Mas se ela pertence ao Sonderkommand, ${ }^{32}$ sabe-se que não é por opção. As poucas menções ao judaísmo soam forçadas e falsas.

A referência ao povo eleito por Deus na Bíblia Hebraica é realçada com sarcasmo pelo Carcereiro, apresentado como prisioneiro judeu. Ele insinua uma questão: onde estaria Deus que não protege seu povo? Questão retomada pelos teólogos judeus que refletem sobre o Holocausto e enfrentam essa e outras perguntas: a Aliança de Deus com Israel foi abalada como resultado do massacre na Europa? A catástrofe poderia ser uma punição vinda de um Deus misericordioso? Sendo os judeus o povo eleito, o Holocausto abalou a ideia de Aliança entre Deus e Israel ${ }^{33}$ Mas a menção na peça é ligeira e não avança. Assim também a referência ao deus judaico:

“Joalheiro (grita): Adonai! Claríssima morada!” (p. 51)

Se o apelo fosse a Cristo, ou simplesmente a Deus, não soaria estranho; não existe a prática, entre judeus, de apelar por Adonai e menos ainda atribuir-lhe uma morada. Também a história contada pelo Estudante, de um rei que tinha três filhos e presenteou a cada filho com uma coroa. Na tentativa de lembrar o nome das coroas a personagem soletra duas letras do alfabeto hebraico "alef" e "iod" (a primeira e a última letra de um dos nomes de Deus - Adonai), lembrando-se em seguida da terceira: Penitência. Aqui há uma clara passagem sem mediação do judaísmo ao cristianismo - o foco real da peça.

Hilda Hilst centraliza na figura do padre Maximilian Kolbe o eixo do seu interesse. Consta em sua biografia que a mãe de Cristo ter-lhe-ia aparecido na infância com duas coroas: uma branca, outra vermelha, para que escolhesse uma. A branca significava a perseverança na pureza, a vermelha, que se tornaria mártir. Ele escolheu aceitar as duas. Desde criança Kolbe acreditava-se destinado ao martírio. Na Polônia foi preso e enviado a Auschwitz por ajudar judeus e outras minorias perseguidas. Ali, de fato, o padre ofereceu-se para morrer em lugar de outro prisioneiro. Kolbe foi beatificado pelo Papa Paulo VI, em 1970, e canonizado como mártir pelo Papa João Paulo II, em 1981. ${ }^{34}$

A palavra "mártir" provém do grego e significa "testemunha”. Ela foi empregada nos primórdios do Cristianismo para indicar os Apóstolos e os primeiros discípulos que, tendo presenciado os milagres e a ressurreição de Jesus, derramaram seu sangue para testemunhá-lo. Posteriormente, o termo foi utilizado em sentido mais amplo, para designar os cristãos que preferiram a morte a renegar sua fé. Na linguagem eclesiástica, a palavra "martírio" refere-se, pois, ao testemunho da verdade cristã, selada com o sangue, até o sacrifício da própria vida, à semelhança de Cristo. O martírio constitui, para os cristãos, 
um ato supremo de virtude e o mais perfeito ato de caridade. É dele que Maximilian vai lançar mão para enfrentar o mal. Mas esse mal é abstrato, tem poucas configurações ou índices que permitam sua identificação com o nazismo. Este é referido através dos SS e da menção ao Führer ou a Hitler com aparição relâmpago na peça, quando se ouve seu discurso através do alto falante (p. 44). Ele apresenta-se como o oposto de Cristo e de Maximilian. Nas palavras do Estudante: "[...] Ele é o reverso, você sabe? O reverso. O outro rosto de cada um de nós.”

O sofrimento da tortura ou da aniquilação física é provocado pelo mal humano, que o homem alberga dentro de si, exigindo, na peça, a vigilância do bem, enfrentado sob forma martirológica. Não há como vencer o mal, mas há formas de mitigá-lo. As personagens ilhadas recorrem, como já visto, a lembranças do passado (espaço aberto em oposição à clausura da cela; claro em oposição a escuro; alegria em oposição a aniquilamento; amor em oposição à morte) como forma de resistência ao enfrentamento da morte, que tem na figura do Padre o possível alívio por meio da penitência e do amor.

O propósito de tratar da necessidade de resistência faz a autora trabalhar com um "documento de barbárie" - para usar a expressão de Walter Benjamin - emblematicamente representado pelo campo de extermínio de Auschwitz/Birkenau. Seu interesse é amplo e, por isso mesmo, vago: denunciar o sofrimento e a aniquilação perpetrada por uns a outros. Daí a ausência de dados referenciais. A escolha do campo de concentração e do Hocolausto tem a ver com a inserção do Padre Maximilian e também com o desejo de construir uma alegoria através do mais terrível dos episódios de barbárie do século XX e fazer que esse episódio aluda a todos os demais, incluindo aí a ditadura militar brasileira, que remete ao momento presente em que a peça foi escrita. Não é de se negligenciar a data da publicação da peça 1968, inscrita abaixo do título, alertando o leitor.

O golpe militar brasileiro pôs abaixo o governo constitucional de João Goulart, em 1964. Em 13 de dezembro de 1968, com a decretação do Ato Institucional $\mathrm{n}^{-\mathrm{a}}$ 5, o regime ditatorial endurece e centenas de opositores são presos. Entre alguns centros de resistência no período, destaco o Grupo Opinião, cujo teatro, à Rua Siqueira Campos, tornou-se uma espécie de centro que trabalhava na contramão do regime autoritário; a editora Civilização Brasileira de Ênio da Silveira, em torno de quem se reunia um grande número de intelectuais renomados. Cito, ainda, o papel ativo da esquerda católica através das Comunidades Eclesiais de Base (CEBs) no enfrentamento da repressão ditatorial.

Lembro que esse paradigma da libertação como agente norteador do discurso teológico latino-americano surgiu na 
35. Outro nome para designar o Holocausto. Do hebraico, significa "catástrofe".

36. Pogrom: agressão organizada e violenta que inclui saque e morte perpetrada contra as comunidades judaicas da Rússia e da Polônia

37. Há uma vasta bibliografia sobre a atuação do Papa Pio XII durante a Segunda Guerra Mundial. Cito o livro de Annie Lecroix-Riz, Le Vatican, L'Europe et le Reich de la première guerre mondiale à la guerre froide, 1996 , por basear seu trabalho em um enorme arquivo de dados.

38. AMARAL, Maria Teresa. "Aves da Noite", Última Hora, 16/09/1982. A informação é provavelmente da própria autora. Cf. Um Teatro da Mulher, Elza Cunha de Vincenzo. São Paulo, Edusp/Perspectiva, 1992, p. 63. década de 60 do século XX. Essa teologia desenvolvida depois do concílio Vaticano II põe grande ênfase na situação social humana e caracteriza-se pela valorização da ação de Deus na história, como fonte de libertação social. Talvez a autora procurasse na figura santificada de Maximilian Kolbe um modelo de resistência ao horror, que servisse de guia para uma parte ativa da igreja católica do Brasil no período da ditadura militar. Entretanto, a construção dessa alegoria despreza as particularidades do que significou o Holocausto.

Inseparável da queda da Europa na desumanidade, a partir da Shoá, ${ }^{35}$ está a designação cristã do judeu como deicida. Dos primeiros pogroms ${ }^{36}$ e massacres que varrem a Renânia na Idade Média ao Holocausto, o percurso é certamente complexo e por vezes subterrâneo, mas também indubitável. $\mathrm{O}$ isolamento, a perseguição, a humilhação social e política do judeu tem sido integrante da presença cristã. Assim, eleger o padre cristão para representar o ocorrido em Auschwitz, elidindo todos os demais dados que incluiriam judeus, ciganos, homossexuais, comunistas e outras minorias, soa estranho, principalmente quando se pensa na atuação negativa do Vaticano em relação ao extermínio. ${ }^{37}$

Quanto à apropriação do Holocausto por escritores, James E.Young, em seu livro Writing and Rewriting the Holocaust - Narrative and the Consequences of Interpretation (1990), no capítulo em que trata da poesia de Sylvia Plath "The Holocaust Confessions of Sylvia Plath" - entre várias referências poéticas à Shoá escritas por não-vítimas, contesta com maior vigor o último livro da autora, Ariel. Diferente de John Berryman, que se tornou um judeu imaginário para poder explorar a ideia do antissemitismo, ou de Anne Sexton, que explicitamente representou o impacto de Auschwitz em si, Sylvia Plath representou a si própria - sua vida - na figura do judeu do Holocausto. Assim, ela não é uma poeta do Holocausto, porque ela não escreveu sobre o Holocausto. Ela escreveu sobre si figurada como uma judia do Holocausto. Sem tentar re-imaginar e re-trabalhar o Holocausto, que para ela não é uma experiência para ser contada ou descrita, a autora incorpora uma idéia traduzida em imagem que lhe permite expressar outra realidade brutal: seu pânico interior.

Retornando à peça de Hilst, é curioso observar que, para metaforizar o mal, a autora utilize os mesmos substantivos que retornam com frequência em seu teatro poético como metáforas do espírito e da elevação humana às mais altas esferas: "pássaro", "asa”, "vôo". É a "noite” que escurece a paleta, cria a inversão e faz o giro do bem ao mal. Isso porque a razão, a ponderação, vinculam-se às luzes iluministas da Razão, enquanto a sombra e a noite passam a seu antípoda. As aves noturnas são predadoras e remetem aos SS que espargem o 
horror sobre os homens. Eles rondam a cela dos prisioneiros, podendo irromper a qualquer instante para acrescentar pavor ao pavor desses homens.

A peça de Hilda Hilst interessou a encenadores entre 1980 e 1982, tendo sido montado primeiro um espetáculo em 1980, e outro em 1982. Nessa ocasião um pequeno artigo de Maria Tereza Amaral afirma que a peça tinha sido escrita entre 1967 e 1968 e "pensada como metáfora da noite brasileira". ${ }^{38}$

Finalizando, chamo a atenção para uma passagem da peça que aviva muitos problemas em debate hoje em dia, quando alude à necessidade de a palavra virar imagem viva, matéria diante dos olhos dos outros: "e então os que vierem serão obrigados a se lembrar de nós...” (p. 30)

Temos aí implicados três conceitos caros à literatura sobre o Holocausto: lembrança, esquecimento e testemunho. ${ }^{39}$

É importante observar que Theodor Adorno ${ }^{40}$ é sutil na maneira como se manifesta a propósito da memória. Ele não afirma que devemos nos lembrar sempre de Auschwitz, mas sim que devemos fazer tudo para que algo semelhante não se repita. Ele não defende as comemorações e as homenagens, mas uma luta contra o esquecimento. Se essa luta é necessária, é porque não só a tendência de esquecer é forte, mas também o desejo de esquecer. Há um esquecimento natural, necessário à vida, dizia Nietzsche. Mas existem outras formas de esquecimento negativas: denegar, recalcar, fazer de conta que não se sabe. Não se trata de tornar o passado presente para permanecer na memória enquanto registro de queixa, recriminação, acusação. Aquele que acusa e se queixa ocupa uma posição de superioridade em relação ao réu e se poupa de alimentar uma atuação esclarecida, reproduzindo o mesmo círculo vicioso de culpados e de vítimas.

Com isso, não pretendo abstrair a questão da culpa, mas lembrar, com Primo Levi, que nos encontramos diante de uma analogia paradoxal entre vítima e opressor, e importa ser claro: "os dois estão na mesma armadilha, mas é o opressor, e só ele, quem a preparou e fez disparar..." ${ }^{\prime 1}$ Por outro lado, quem tem o direito de testemunhar sobre o que aconteceu em Auschwitz? Se a culpa recai sobre o sistema, o estado totalitário como um todo, a quem compete julgar? Basicamente a ninguém, responde Primo Levi, ${ }^{42}$ para quem não é possível "reduzir a rede das relações humanas dos Lager a apenas dois blocos, o das vítimas e o dos opressores". A tendência maniqueísta à simplificação consiste numa hipertrofia do juízo, emblematizado pelo Juízo Final cristão, na divisão da humanidade em dois grupos claramente distintos: o dos bons e o dos maus. A lição do campo, ao contrário, era que "o inimigo estava ao redor mas também dentro, o 'nós' perdia seus limites e os contendores não eram
39. A propósito de "testemunho", remeto ao sentido que lhe outorga Márcio Seligman-Silva, em "O testemunho: entre a ficção e o 'real', quando afirma que para que o mesmo exista é necessária a presença de um terceiro. Ao recuperar as histórias de outros, o sujeito transforma-se em terceiro e, em conseqüência, em testemunho. Cito: "Em latim pode-se denominar o testemunho como duas palavras: testis e supertestes. A primeira indica o depoimento de um terceiro em um processo [...]. Também o sentido de superstestes é importante no nosso contexto: ele indica a pessoa que atravessou uma provação, o sobrevivente. O conceito de mártir está próximo a essa acepção do sobrevivente. Martyros em grego significa justamente testemunha. Se a noção de testemunha como terceiro já anuncia o tema da verificação da 'verdade', ou seja, traz à luz o fato de que o testemunho por definição só existe na área enfeitiçada pela dúvida e pela possibilidade da mentira, a acepção de testemunho como sobrevivente e como mártir indica a categoria excepcional do 'real' que o testemunho tenta dar conta a posteriori." História, Memória, Literatura, org. Márcio Seligmann-Silva. Campinas: Editora Unicamp, 2003, pp 377-378.

40. Cf. o capítulo "O que significa elaborar o passado", de Jeanne Marie Gagnebin, Lembrar escrever esquecer, 2006 , que retoma e discute a Dialética do Esclarecimento de Theodor Adorno e Max Horkheimer.

41. LEVI, Primo. Os afogados e os sobreviventes, 1990 , p.10.

42. Ibidem, p.17. 
dois, não se distinguia uma fronteira, mas muitas e confusas, talvez inúmeras, separando cada um do outro". ${ }^{43}$

Definir o humano a partir de uma essência é, de certa maneira, repetir a lógica SS e sua repartição soberana entre humanidade alemã e inumanidade judaica, entre moral humana alemã, e venalidade sub-humana judaica, entre o patrimônio genético do povo alemão e a "vida nua" dos "piolhos" judeus, exterminados nas câmaras de gás. O novo imperativo talvez seja não apenas lembrar ou esquecer, mas mapear uma nova ética que impeça o circuito da repetição.

É louvável que Hilda Hilst tenha enfrentado tema tão complexo em sua peça. Ela, com certeza, acreditava na função ética do teatro e da arte, em geral, o que a moveu a tratar da morte sem sentido, morte anônima e inumerável que homens impuseram a outros homens - e ainda impõem. 


\section{Referências}

AGAMBEN, Giorgio. Homo sacer. El poder soberano y la nuda vida (trad. Antonio Gimeno), Pre-Textos, Valencia, 1998. [Edição em português: Homo sacer, Belo Horizonte: ed. UFMG, 2006].

AMARAL, Maria Teresa. Aves da Noite. In: Última Hora, 16/09/1982.

BERKOVITS, Eliezer. With God in Hell - Judaism in the Ghettos and Deathcamps. New York, Sanhedrin Press, 1979.

GAGNEBIN, Jeanne Marie. Lembrar escrever esquecer. São Paulo, Editora 34, 2006.

GALLE, Helmut. Sobre la representación del holocausto en el drama alemán. El callejón sin salida del teatro documental. In: Teatro y Teoría Teatral y otros temas germanísticos (Actas de las XII Jornadas de la Asociación Argentina de germanístas) Facultad De Filosofía y Letras. Universidad de Buenos Aires, 2003, pp.79-95.

HILST, Hilda. Teatro completo (org. Alcir Pécora; posfácio Renata Pallottini). São Paulo: Globo, 2008.

HOCHHUT, Rolf. O vigário. São Paulo: Editorial Grijalbo, 1965 [Tradução de João Alves dos Santos]; pp. 275-276.

HUBERMAN, Ariana; METER, Alejandro. Memoria y Representación: Configuraciones culturales y literarias en el imaginário judío latinoamericano. Rosario: Beatriz Viterbo Editora, 2006.

LECRIOX-RIZ, Annie. Le Vatican, L'Europe et le Reich de la première guerre mondiale à la guerre froide. Paris: Arman Colin, 1996.

LEVI, Primo. Os Afogados e os Sobreviventes. Os delitos, os castigos, as penas e as impunidades (trad. Luis Sérgio Henriques). Rio de Janeiro: Paz e Terra, 1990.

RAWET, Samuel. Contos e Novelas Reunidos (org. André Seffrin). Rio de Janeiro: Civilização Brasileira, 2004.

ROSENFELD, Anatol. O teatro de Hilda Hilst. In: Suplemento Literário. O Estado de S. Paulo, 21.01.1969.

SANTO AGOSTINHO. Confissões. Livro XIII, $\mathrm{n}^{-\underline{a}}$ 5: $A$ Trindade Divina. In Os Pensadores, vol. IV, Santo Agostinho, Confissões e De Magistro. São Paulo: Abril Cultural, fev. 1973. Cf. Evangelho de S. Lucas, 23:33. 
SELIGMAN-SILVA, Márcio. História, Memória, Literatura, org. Márcio Seligmann-Silva. Campinas: Editora Unicamp, 2003.

VINCENZO, Elza Cunha de. Um Teatro de Mulher. São Paulo: Edusp/Perspectiva, 1992.

WALDMAN, Berta. La Shoá en la literatura brasileña: una pequeña gramática. In: Memoria y Representación: Configuraciones culturales y literarias en el imaginário judío latinoamericano. Ed. Ariana Huberman y Alejandro Meter. Rosario: Beatriz Viterbo Editora, 2006, pp. 103-123.

WIEVIORKA, Annette. Auschwitz expliqué à ma fille. Paris: Seuil, 1999, p. 26.

YOUNG, James E. Writing and Rewriting the Holocaust - Narrative and the Consequences of Interpretation. Bloomington and Indianopolis: Indiana University Press, 1990. 